HUOM! Tämä on alkuperäisen artikkelin rinnakkaistallenne. Rinnakkaistallenne saattaa erota alkuperäisestä sivutukseltaan ja painoasultaan.

Käytä viittauksessa alkuperäistä lähdettä:

Pedro, R., Mendes, J., Matos, N., \& Ascenção, M. (2020). A conceptualization of the senses, emotions, and memories in memorable tourism experiences. Teoksessa P. Pinto \& M. Guerreiro (toim.), Handbook of Research on Resident and Tourist Perspectives on Travel Destinations (ss. 208-231). Hershey, PA: IGI Global. DOI: 10.4018/978-1-7998-3156-3.ch010

PLEASE NOTE! This in an electronic self-archived version of the original article. This reprint may differ from the original in pagination and typographic detail.

Please cite the original version:

Pedro, R., Mendes, J., Matos, N., \& Ascenção, M. (2020). A conceptualization of the senses, emotions, and memories in memorable tourism experiences. In P. Pinto \& M. Guerreiro (Eds.), Handbook of Research on Resident and Tourist Perspectives on Travel Destinations (pp. 208-231). Hershey, PA: IGI Global. DOI: 10.4018/978-1-7998-3156-3.ch010

The final publication is available online: https://www.igi-global.com/gateway/chapter/258651

(C) IGI Global 


\title{
Chapter 10 \\ A Conceptualization of the Senses, Emotions, and Memories in Memorable Tourism Experiences
}

\author{
Rui Mendonça Pedro \\ Faculty of Economics and Research Centre for Tourism, Sustainability, and Well-Being (CinTurs), \\ University of Algarve, Portugal \\ Julio Mendes \\ Faculty of Economics and Research Centre for Tourism, Sustainability, and Well-Being (CinTurs), \\ University of Algarve, Portugal \\ Nelson de Matos \\ School for Management, Hospitality and Tourism (ESGHT) and Research Centre for Tourism, \\ Sustainability, and Well-Being (CinTurs), University of Algarve, Portugal \\ Mário Passos Ascenção \\ iD https://orcid.org/0000-0002-0536-0860 \\ Haaga-Helia University of Applied Sciences, Finland
}

\begin{abstract}
This chapter explores a conceptualization of the elements that create a memorable tourism experience - senses, emotions, and memories. A comprehensive and coherent theoretical model is established to explain the complexities involved in the tourism experience creation (tourism experience relational model) and in the memorable tourism experience (conceptual model). The data suggest that, first, the senses developed an important role in the experiential stimuli perception; second, the emotions are fundamental to these experiential stimuli understanding and meaning creation, and third, memory is essential in the codification and storage process and anticipation of meaningful information to future
\end{abstract}


experiences. The conceptual model is based on the five senses (sight, smell, taste, hearing, and touch), three positive emotions (joy, love, and positive surprise), and two memorable elements (recollection and vividness). Future research opportunities in the memorable tourism experience are explored, such as the relation between the sense, emotions, and memories.

\section{INTRODUCTION}

In the current global economic context, tourism experiences represent a key value proposal for the tourism sector and specifically for tourists, because they wish to engage in unique experiences (Mendes, Guerreiro, \& Matos, 2016). Touristic companies and organizations compete to offer the richest possible experience to appeal to tourists' wishes and desires (Boswijk, Thijssen, \& Peelen, 2006; Pine \& Gilmore, 1998; Schmitt, 1999). Ayazlar and Arslan (2017) and Stasiak (2013) consider that the tourism industry is one of the areas of excellence in presenting and staging experience according to a commercial structure that is demanding in terms of services and products specificity, as well as intangible and seasonal. The tourism experience is, however, a complex, personal and memorable construct (Pine \& Gilmore, 1998; Zhang, Wu, \& Buhalis, 2018).

The memorable tourism experience (MTE) allows tourists to revive, remember and revisit the experiential moment through recollection processes that will last forever or continue for a long period. MTE are considered the ultimate goal that tourists want to achieve during their holidays (Tung, Lin, Zhang, \& Zhao, 2017), because they are recognized by tourists as satisfactory, enjoyable and pleasurable moments (Chen \& Rahman, 2018; Zhang et al., 2017). MTE also contribute to increasing the tourists' intention to revisit, remember and recommend a destination (Kim, 2018).

Several articles have shown the importance of the senses in the tourism experience (Agapito, Mendes, Valle, \& Almeida, 2014; Goggin et al., 2017; Lee, Heere, \& Chung, 2013; Meacci \& Liberatore, 2015), while others have studied the significance of the emotions (Correia, Oliveira, \& Pereira, 2017; Hosany, Prayag, Deesilatham, Cauševic, \& Odeh, 2015; Prayag, Hosany, Muskat, \& Del Chiappa, 2017; Shoval, Schvimer, \& Tamir, 2018) and some articles have considered the influence of memories (Ali, Hussain, \& Ragavan, 2014; Kastenholz, Carneiro, Marques, \& Loureiro, 2017; Pezzi \& Vianna, 2015; QuadriFelitti \& Fiore, 2013). The relationship between the senses, emotions and memories is, however, a theme on which there has been a lack of attention (Dias, Correia, \& Cascais, 2017).

This chapter therefore investigates the role of senses, emotions and memories in the MTE. The objectives of this chapter are fivefold: first, to enhance and identify the state of the art regarding the senses, emotions and memories in the tourism context; second, to clarify the importance of the senses, emotions and memories in the tourism scenario; third, to develop a conceptual framework of the senses, emotions and memories in the memorable tourism experience; fourth, to analyse future research opportunities in this area; and fifth, to clarify the relationship between the senses, emotions and memories in MTE creation.

This chapter is divided into three main sections. The first section introduces the theme and the relevant contributions and articles. In the second section, the background, the authors provide a brief review of the experience paradigm (i.e. dimensions, models and definitions), the tourism experience approach and 
tourism experience relational model are presented. In the same section, the role of senses, the influence of emotions, the effects of memories in the MTE are considered. the researchers also present the conceptual frameworks to represent the relationship between the senses, emotions and memories in creating an MTE. The paper closes with a conclusion that focuses on the aims of the study.

\section{BACKGROUND: THE EXPERIENCE PARADIGM}

The experience paradigm is a crucial issue that is present in several areas, from the economy to tourism, from industry to business and from products to services (Adhikari \& Bhattacharya, 2016; Carbone \& Haeckel, 1994; Chang \& Lin, 2015; Duncan, Fanderl, Maechler, \& Neher, 2016; Holbrook \& Hirschman, 1982; Rais, Musa, \& Muda, 2016; Schmitt, Joško Brakus, \& Zarantonello, 2015). Experience as a concept can be outlined as complex process between a customer and the environment in which fantasies, feelings, emotions and fun are involved (Holbrook \& Hirschman, 1982). The experience process can also be considered something extraordinary, in which multisensory stimulants, involving all five senses (Carù \& Cova, 2003; Shaw, 2005), and emotionally surprising factors are present (Andajani, 2015; Berry, Carbone, \& Haeckel, 2002) to fulfil customers' needs and expectations (Gentile, Spiller, \& Noci, 2007; Nasution, Sembada, Miliani, Resti, \& Prawono, 2014) with the purpose of becoming a memorable event (Chahal, Kaur, \& Rani, 2016; Pine \& Gilmore, 1998).

For instance, Lemon and Verhoef (2016, p. 74), conceptualize the customer experience as a stage process or "as a cycle journey, (...) an interactive and dynamic process (...) flows from pre-experience to experience and to post-experience (...) between a company and a customer". The experiential process comprehends different stages with distinct customer behaviours. The pre-experience stage includes customers' search for information, their personal dreams and wishes reflected in the imagination and mental experiences they anticipate experiencing during their vacations, as well as price analysis between options, interactions with the brand(s) and evaluation of several options in comparison with previous experiences. The experience stage covers all of the customer's experience interaction and includes decision-making (choice and ordering), experience consumption, experience creation or co-creation and payment. The post-experience stage comprehends the following behaviours: outcome evaluation, satisfaction, loyalty and consideration for future experiences (Arnold \& Reynolds, 2003; Lemon \& Verhoef, 2016; Peñaloza \& Venkatesh, 2006; Tynan \& McKechnie, 2009; Verhoef et al., 2009). During the experiential journey, the customer also goes through different experience stages (Chahal et al., 2016; Nasution et al., 2014; Tynan \& McKechnie, 2009), with different interactions and behaviours (Baxendale, Macdonald, \& Wilson, 2015; Dhebar, 2013; Lemon \& Verhoef, 2016) facing different dimensions of the experiential process (Brito, Oliveira, Nobre, Macedo, \& Marchetti, 2017; Pine \& Gilmore, 1998; Schmitt, 1999).

The experience occurs when the customer is exposed to the consumption (of a service or product) and "this experience journey is composed by dimensions linked to the interaction between a customer to service or a customer to product" (Brito et al., 2017, p. 125). There is no agreement on the dimensional terminology among authors on this subject (Dias et al., 2017; Krishna \& Schwarz, 2014; Pine \& Gilmore, 1998; Schmitt, 1999). Pine and Gilmore (1998) distinguish two dimensions - customer participation and customer connection - within four realms: entertainment, educational, aesthetic and escapist. Schmitt (1999), in its turn, proposes five dimensions/modules: relate, sense, feel, think and act. Numerous studies have also already contemplated a multidimensional approach. In effect, several dimensions emerge from the tourism experience theme: the sensorial dimension (Dias et al., 2017; Krishna, 2012; Krishna \& 
Schwarz, 2014; Zatori, Smith, \& Puczko, 2018), the emotional dimension (Correia et al., 2017; Dias et al., 2017; Oh, Fiore, \& Jeoung, 2007), the memorable dimension (Dias et al., 2017; Hosany \& Witham, 2010; Kim, Ritchie, \& McCormick, 2012; Oh et al., 2007), the social dimension (Foris, 2014; Ivanovic \& Saayman, 2015), the spiritual dimension (Jepson \& Sharpley, 2015) and the physical dimension (Cohen \& Ben-Nun, 2009; Fernandes \& Cruz, 2016; Jepson \& Sharpley, 2015).

According to Gentile et al. (2007), Kim et al. (2012) and Zatori et al. (2018), tourism experiences with high sensorial immersion and with stimulation of the five senses is essential to promote the long-term memory process. This is the case because sensorial perception is strongly related to emotional activation, emotional activation and processing involve cognitive functions and, finally, using high emotional and cognitive resources increases memory construction and consolidation (Zatori, 2013). (Dias et al., 2017, p. 190) also state that the tourism experience "must be memorable and evoke emotions: if this does not occur, its future will end soon". Overall, the dimensions are closely linked to sensorial, emotional, rational and social aspects (Dirsehan \& Çelik, 2011) through hedonic activities - that is, pleasure, joy, fun and fantasy (Schmitt, 1999) - and during the experiential process, the experience dimensions emerge with an organized structure and are presented according to time, intensity, polarity, action and experience specificity, similar to multidimensional experience models (Carù \& Cova, 2003; Chan, To, \& Chu, 2016; Fave \& Bassi, 2016; Pine \& Gilmore, 1998; Schmitt, 1999; Wang, Tang, Liu, \& Xing, 2017).

The tourism experience is perceived by tourists according different models (Cohen, 1979; Ek, Larsen, Hornskov, \& Mansfeldt, 2008; Gelter, 2010; Jennings, 2005; Killion, 1992; Tussyadiah, 2014). Csikszentmihalyi (1990) was one of the first authors to develop an experiential model: the flow theory or optimal experience. Years later, the same author reformulated flow theory and added task challenge, skill level, subject involvement and commitment to the model (Csikszentmihalyi, 2014). The flow theory or optimal experience "is a psychology state of intense concentration, attention and proper stimulation (...) and occurs when the subject experience the balance between task challenge and skills level (...) which results in a completely involvement, (...) forgetting time, fatigue, and everything else but the activity itself (...) during a transcendental and singular moment" (Csikszentmihalyi, 2014, p. 230). From a less transcendent and more economic point of view, Pine and Gilmore $(1998,1999)$ developed the four realms model based on four dimensions (entertainment, educational, aesthetic and escapist), the experience involvement level (absorption and immersion) and the experience participation level (active and passive). Schmitt (1999) developed the experiential grid model (ExPros) that relates the five modules (relate, sense, feel, think and act) according to the experience levels of intensity, breadth, depth and linkage. In a distinct, more unidirectional perspective, Carù and Cova (2003) created the extraordinary experience model, which underlines that, during the experiential process, "it manages to over-saturate all events to construct a long series of strong emotions and unforgettable and extraordinary experiences" (Carù \& Cova, 2003, p. 281).

Presently, one of the most used models of tourism experience is the co-creation model (Hsieh \& Chang, 2016; Lin, Chen, \& Filieri, 2017; Ramaswamy \& Ozcan, 2018). This model allows active participation, tourist interaction during an experience (Cabiddu, Lui, \& Piccoli, 2013; Campos, Mendes, Valle, \& Scott, 2015; Prebensen, Vitterso, \& Dahl, 2013) and improves the experience process outcomes (Buonincontri, Morvillo, Okumus, \& van Niekerk, 2017; Campos, Mendes, Valle, \& Scott, 2017; Prebensen \& Xie, 2017; Ribes-Giner, Perello-Marín, \& Díaz, 2016). Meanwhile, the tourism experience must be perceived through a global, multidimensional and holistic approach (Gentile et al., 2007). Thus, despite the various presented conceptual models of the experiential process, it seems that experience remains an elusive and complex construct, linked to the personal domain and multiple dimensions that are yet to 
be fully understood and explained (Boswijk et al., 2006; Carù \& Cova, 2003; Csikszentmihalyi, 2014; Pine \& Gilmore, 1998).

Experience is a rich construct in terms of its multiple contents (Adhikari \& Bhattacharya, 2016; Lemon \& Verhoef, 2016; Stein \& Ramaseshan, 2016; Tynan \& McKechnie, 2009; Verhoef et al., 2009), dimensions (Chan et al., 2016; Ding \& Tseng, 2015; Dirsehan \& Çelik, 2011; Pine \& Gilmore, 1998; Wang et al., 2017) and explanatory models (Carù \& Cova, 2003; Csikszentmihalyi, 1997, 2014; Fave \& Bassi, 2016; Gentile et al., 2007; Pine \& Gilmore, 1998; Schmitt, 1999). Experience should, however, include a model that addresses the relationship between an organization and a subject throughout the different experiential process stages, touch points and dimensions and finish with experience effects and results to the company and the subject. The experience is an organized, dynamic process that involves interactions between a company and a customer with the purpose of creating extraordinary, personal, emotional and memorable moments to foster customer loyalty (Adhikari \& Bhattacharya, 2016; Carù \& Cova, 2003; Chan et al., 2016; Csikszentmihalyi, 2014; Ding \& Tseng, 2015; Dirsehan \& Çelik, 2011; Gentile et al., 2007; Lemon \& Verhoef, 2016; Pine \& Gilmore, 1998; Stein \& Ramaseshan, 2016; Tynan \& McKechnie, 2009; Verhoef et al., 2009; Wang et al., 2017).

Some authors consider experiences to be extraordinary moments and transcendent events (Kirillova, Lehto, \& Cai, 2017) that consist of "a process of exploring consciousness (...) that is ever-present in human life (...) and how this consciousness interacts with the world" (Chen, Scott, \& Benckendorff, 2017, p. 2). Such experiences can be operationalized through the search for new and different encounters to escape the monotony of daily routine, a search for authenticity, local interactions and engagement with natural landscapes (Park \& Santos, 2017).

\section{THE TOURISM EXPERIENCE}

Tourism experiences provide the source of value in the evolution, dynamics and competition in tourism destinations and for the tourism industry (Ali, Ryu, \& Hussain, 2016; Bosangit, Hibbert, \& McCabe, 2015; Campos, Mendes, Valle, \& Scott, 2016). Given their importance, one of the fundamental concepts in the tourism context is the tourism experience, because it establishes the basis of services and product supply (Fernandes \& Cruz, 2016). The perceived quality of tourism experiences has a crucial impact on tourists' satisfaction and loyalty, and it represents an essential factor in tourism management and hospitality industry strategy (Demarco, 2016). Chang (2018, p. 55) notes that "tourism industry revenue increases according to the extent to which consumers enjoy their experiences". The central issue in tourism is, therefore, the tourism experience (Bosangit et al., 2015; Demarco, 2016; Kim, 2010) and its management regarding the capacity to offer, stage, create and co-create such experiences in ever more multisensory, emotional and memorable events (Kim, 2018; Vo Thanh \& Kirova, 2018).

According to Kirillova, Lehto and Cai (2017, p. 498) "tourism experiences are distinct from the everydayness because they can become extraordinary, pure, peak or cathartic (...) thus special extraordinary events trigger highly emotional responses, lead to self-exploration, serve for profound intrapersonal changes and are conducive to optimal human functioning". However, the tourism experience concept should include novelty, unusual places (social interaction), loneliness (relaxation) and sensory stimulation (Morgan, 2006; Mossberg, 2007). Larsen (2007) brings the role of memory to the discussion and, more specifically, that the experience event should be iconic enough to enter the long-term memory. Volo (2009, p. 119) describes the experience with a more physiological perspective, noting 
that a touristic experience happens when "energy reflecting the state of the environment impinges on sensory organs, the energy pattern is transmitted centrally and is interpreted and categorized according to one's knowledge acquired through time and is integrated and may be stored in the form of memory under some conditions".

The main advantages of the touristic experience to tourists are behaviour change and self-discovery (Kirillova et al., 2017), physical wellness and psychological benefits (Chen et al., 2017; Tung et al., 2017), general satisfaction and mental well-being (Fernandes \& Cruz, 2016; Martins et al., 2017; Park \& Santos, 2017) and the chance to live extraordinary moments or spiritual experiences that evoke memories through cognitive activity (Chen et al., 2017). Tourism quality involves multiple influences such as the tourist, the local population and the touristic product (Nickerson, 2005), so "a quality experience, (...) depends on how each side is treated by the other" (Nickerson, 2005, p. 233).

\section{Tourism Experience Relational Model}

The experience relational model always includes a sender, a message sent through a channel, a receiver and then the feedback (see Figure 1). During the creation stage, instruments are delivered and all context staging belongs to the organization (Carù \& Cova, 2003; Pine \& Gilmore, 1999). The message is established, transmitted and shared throughout the experience between the organization and the tourist based on the tourist's multisensory stimulation and emotional involvement (Andajani, 2015; Carù \& Cova, 2003; Shaw, 2005). The feedback comprehends the experiential outcomes between the tourist and the organization, such as satisfaction, attractive moments, extraordinary events and memorable moments (Hosany, Prayag, Van Der Veen, Huang, \& Deesilatham, 2017; Kim \& Jang, 2016; Kim \& Ritchie, 2014; Prayag, Hosany, \& Odeh, 2013).

It is clear that, in tourism, the focus is the experience (Duarte, 2012, p. 187), and tourists "want experience more than a product or service because they are more memorable (...) and (...) in the baggage they bring expectations and takes home memories" (Ayazlar \& Arslan, 2017, p. 137). Memorable tourism experiences provide competitive advantage to tourists, destinations, hospitality industries and hotel companies among other stakeholders (Kim \& Youn, 2017; Tung et al., 2017).

\section{THE MEMORABLE TOURISM EXPERIENCE}

"A memorable tourism experience is a past personal travel-related event strong enough to have entered long-term memory" (Larsen, 2007, p. 15). Other authors describe a memorable tourism experience as a sufficiently significant moment that is recalled and reconstructed by the tourist in describing the experience (Tung et al., 2017; Tung \& Ritchie, 2011). More recently, Kim et al. (2012, p. 13) state that "a tourism experience positively remembered and recalled after the event has occurred". However, other authors note that a tourism experience is a personal journey and only becomes memorable according to the tourist's personal interpretation, meaning assignment and based on culture, beliefs, values and behaviours (Ayazlar \& Arslan, 2017; Chen \& Rahman, 2018; Tsai, 2016).

According to Park and Santos (2017), this personal journey or process reveals that a memorable tourism experience is a sequential process with multiple stages (pre-experience, experience and postexperience) that is dynamic (interaction with others, with destiny) and personal (built through tourist expectations, needs, motivations, perceptions, emotions, memories). This personal journey is associated 
Figure 1. Tourism experience relational model Source: Own Elaboration

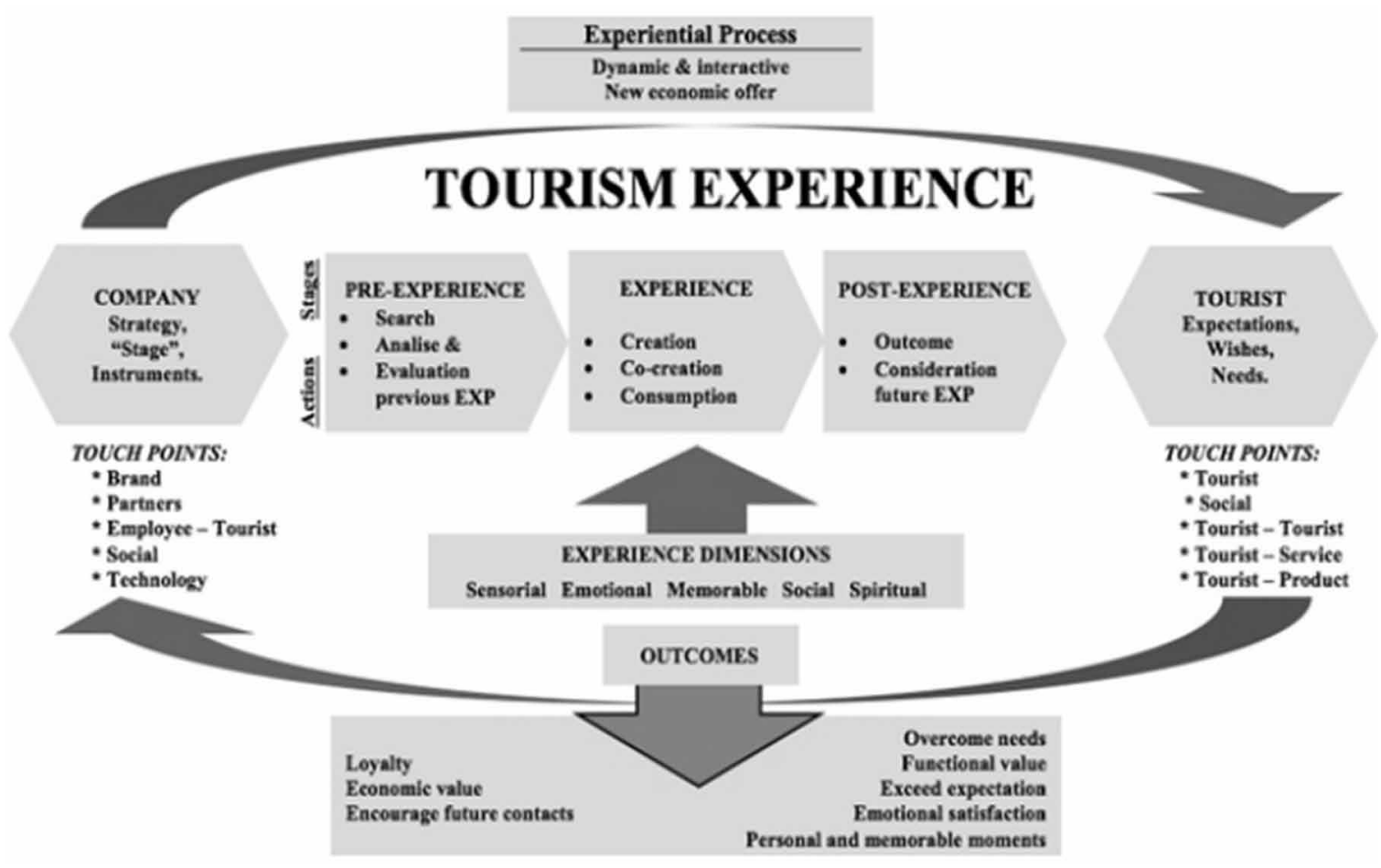

with a subjective sense of well-being, pleasure (hedonism), enjoyment, excitement, self-discovery, meaning, intellectual relevance and connection to something unforgettable and extraordinary (Chandralal \& Valenzuela, 2015; Sthapit \& Coudounaris, 2018; Tung et al., 2017). However, Kirillova et al. (2017) propose that memorable tourism experiences construct and must be considered an unusual event that triggers intense emotional responses and provides a sense of full harmony with the universe. A memorable experience therefore includes a multisensory dimension (Tsai, 2016) and is linked with a sense of well-being, intense positive emotional states, moments of self-discovery, personal meaning and intellectual relevance for tourists (Kirillova et al., 2017; Servidio \& Ruffolo, 2016; Sthapit \& Coudounaris, 2018). In simpler terms, the memorable experiences aims to develop a strong connection between the experience and the tourist (Tsai, 2016).

The characteristics of the memorable tourism experience are linked to the five senses (Agapito, Valle, \& Mendes, 2014; Sthapit, 2017; Sthapit \& Coudounaris, 2018), novelty and escape from everyday life (Kastenholz et al., 2017; Kim, 2010; Kim et al., 2012), while at the same time seeking to exceed expectations and build nostalgia (Tung \& Ritchie, 2011). The memorable experience includes high positive emotional states, cognitive activity and a sense of freedom, refreshment and spiritual connection to something big or extraordinary (Ali et al., 2014; Kastenholz et al., 2017; Kim, 2010; Kirillova et al., 2017; Tung et al., 2017; Zhang et al., 2017). 


\section{The Role of Senses}

The senses or the five sensory organs (sight, taste, hearing, smell, and touch) are the channels of communication between the brain and the outside world (Dias et al., 2017). According to Light (2009, p. 12), "the sensory receptors are anatomical structures made up of special cells (nerve cells or neurons) that respond to specific changes in their environment (stimulus) (...) provide to the central nervous system (brain and spinal cord) information about conditions both inside the body (internal homeostasis) and outside the body (environment information) (...) sensory receptors are the physical links between central nervous system and the environment". The sensory receptors can classified in three different ways based on type of sensation or modality, the location of the stimulus to which they respond and their structural complexity (Light, 2009). Sensory stimulus promotes sensations and the sensations create a perception, because the sensory organs activate and transform external stimulus in neural signals (Agapito et al., 2014; Light, 2009). To Agapito et al. (2014), the sense most often considered in the tourism field is the analysis of the visual dimension. However, Krishna (2012) notes that tourism product has a multisensory nature, and other sensory stimuli are present, including taste, hearing, smell, and touch, that can be determinants to stimulate other sensory organs and create new and distinct sensations and build new neural signs.

In the same context, but from a marketing perspective, Krishna and Schwarz (2014) state that products or services are designed to appeal to the basic senses, and this seems to play an important role in consumers' emotional engagement with the product or service and the development of purchase desire. A more complex idea of the tourism experience suggests that all five senses or a multisensory approach should be considered in, for example, gastronomic experiences and destination products (Ditoiu \& Căruntu, 2014; Jalis, Che, \& Markwell, 2014). The concept of the multisensory tourism experience seems to be a relevant and contemporary research subject, because the senses are the main channel for how the tourist collects and uses information from the environment. All tourism destinations have unique and distinct sensory characteristics, which play an important role in creating tourist loyalty (Agapito, Mendes, \& Valle, 2013; Dann \& Jacobsen, 2003; Jalis et al., 2014; Pawaskar \& Goel, 2014).

As Kim and Fesenmaier (2015, p. 2) note, "the sensorial process is the core role of the tourism experience (...) and starts where the environmental stimuli come across the human body's sense organs (...) the emotional and cognitive responses" According to Krishna (2012), the tourism experience can be viewed on four levels: the sensory level and stimulus reception; the perceptive level and stimulus interpretation; the cognitive and emotional level, where the tourist's cognition and emotional response to the world around them takes place; and the action level, where the transformation of attitudes, learning behaviour and memory processes happen.

In the tourism context, Agapito, Mendes, Valle and Almeida (2014) suggest that the sensory dimension of the tourist experience appears to be strongly linked to positive, unique and memorable experiences, and they therefore developed a study to analyse the sensory dimension of the tourist experiences in a rural context, concluding that the most references senses were to sight (26\%), hearing (23\%), taste (19\%), smell (17\%) and finally, touch (15\%). Each sense is, however, stimulated by different and specific environmental settings and provides different sensory information. The entire sensory component (the multisensory stimulus) allows tourists to achieve an experience more truly meaningful and personalized (Kim \& Fesenmaier, 2015) and therefore more memorable. These personalized experiences suggest specific stimuli to provide memorable moments. Tourism experiences that include a multisensory offer therefore appear to contribute to the reinforcement of positive emotions, satisfaction and the creation of 
long-term memories and destination loyalty (Agapito et al., 2013; Ditoiu \& Căruntu, 2014; Pawaskar \& Goel, 2014).

\section{The Influence of Emotions}

These personalized experiences are present in modern consumer goods and services, which attempt to enable tourists to experience feelings, emotions and stories (Jensen, 2001). Consumers' emotional satisfaction should thus be one of the strengths in an evermore competitive market. It is, however, possible that current tourists not only want a holiday, but also the opportunity to experience new dreams and adventures that embody feelings, spirituality and emotions to satisfy the human nature. Emotions give meaning to the tourist experience, making the experience into something unique, personal, memorable, transcendent, irreplaceable and magnificent, and can manifest themselves before, during and/or after the experience (Prayag et al., 2017). When a tourist, a guest or a visitor looks for new experiences, it is mostly in search of emotions and memories (Kim, 2010).

Damásio (2010) notes that emotions are complex and automatic functions that are characterized by ideas and certain ways of thinking, but emotions are performed on the body, at the external level, through facial expressions and body postures, and at the internal level through endocrinal and visceral changes. Deak (2011) considers emotions to be a complex phenomenon of model behaviour or biological, social and cognitive reaction patterns. This means that emotions can float between the emotional level and the rational level, and this transforms emotions into something more than just a basic and a survival biological behaviour (Dalgleish, 2004; Deak, 2011; LeDoux, 2012). To Deak (2011), emotions are crucial to facilitating understanding of others' cognitive processes.

According to LeDoux (2012), emotions are a biological behaviour necessary for survival and a human self-protection action. However, Perritano (2011) states that emotions can be shaped by culture and society, and characterization of emotions as good or bad can be culturally dependent "in the United States, children are encouraged to take pride in their accomplishments (...) in India, children may heel happier when they have been obedient or helpful", as too are rules about showing emotions "real men don't cry (...) stay calm, don't be angry" (Perritano, 2011, p. 33). Emotions thus have plasticity and adaptability at the cognitive (Deak, 2011), social and cultural levels (Perritano, 2011). Salmela (2014) states that emotions are based on a cognitive characteristic with intentional, rational and voluntary behaviour.

In their study, Pentus, Mehine and Kuusik (2014) changed the product appearance through package design to become more attractive to consumers and found that changes in the visual appearance of the packaging generated positive emotions among consumers, thus unconsciously enhancing likelihood of purchasing. They demonstrated that positive emotions may make consumers more purchasing suggestive, and the emotional response patterns are similar for consumers and tourists (Pentus et al., 2014).

In the tourism context, in a study carried out by Chandralal and Valenzuela (2013), tourists were asked to highlight the emotions that occurred during memorable experiences; the findings indicated that tourists' most common emotions were happiness, enjoyment, surprise, pleasure, satisfaction and excitement, which means that memorable experiences are those that have these as an emotional basis. Güzel (2014) notes that the most satisfying, meaningful and memorable tourist experiences are the ones that cause most emotional excitement. The same author also studied tourist loyalty and the touristic experience and confirmed that tourist's intentional loyalty comes depends on a touristic experience of great emotional excitement (Guzel, 2014). 
Consumption of goods or services is currently seen as an emotional decision-making process (Chandralal \& Valenzuela, 2013; Guzel, 2014; Pentus et al., 2014). It is important to identify the most pleasant emotions for the consumer and to define the stage of the decision-making process in which the emotions will be most perceptible. The level of emotional arousal will lead the consumer to have the intention to repeat the same emotion. The tourism industry is an economic activity that sells unique, memorable and personal experiences (Pine \& Gilmore, 1998). More than experiences, however, the tourist searches for emotions (Bosangit et al., 2015). Emotions in tourism are the key element to the continuous process of renovation, remodelling and recreation that quality tourism requires. Emotions play a key role as mediating and moderating factor of tourism consumption (Pyke, Hartwell, Blake, \& Hemingway, 2016). Emotions in the tourism context establish the link between the tourist and the destination, product or service and provide tourism loyalty, help memory building, increase consumption, support the decisionmaking process and encourage word-of-month advertising (Bosangit et al., 2015; Buda, D'Hauteserre, \& Johnston, 2014; Correia et al., 2017).

\section{The Effects of Memories}

Humans have two memory structures - the amygdala and the hippocampus (Phelps, 2004). These two distinct brain structures are connected to two independent memory systems with different functions and characteristics. In emotional situations, the amygdala can code and store memory in the hippocampus, and the hippocampus, through the emotional representation and interpretation of events may influence the amygdalar responses when emotional stimuli are found (Phelps, 2004; Rahmann \& Rahmann, 1992). Although these are independent memory systems, they operate together when emotion creates the memory links (Phelps, 2004; Rahmann \& Rahmann, 1992).

The role of memory in the brain is somewhat mysterious (Marx \& Gilon, 2012). Moreover, according to Rahmann and Rahmann (1992) and Marx and Gilon (2012), there are different types of memories: active memory, declarative memory, passive memory, associative memory, short-term memory, long-term memory and super-memory. To Marx and Gilon (2012), memory emerges from the dynamic interaction of three physiological mechanism: neurons, the extracellular neuronal matrix and the dispersion of trace metal cations. This tripartite physiological mechanism involves low energy resources and high-speed information processing, and memories are coded by the neurons, while memory losses occur in the presence of excess dispersion of metal cations (Marx \& Gilon, 2012).

Memory formation is a highly dynamic process involving both formation and transformation (Nadel, Hupbach, Gomez, \& Newman-Smith, 2012). Memory formation and transformation require an experience process, and memory transformation can involve: a process of selective strengthening of some behaviours through synaptic rescaling or a process of selective survival behaviour; the assimilation of new information into existing knowledge stores; the establishment of new connections within existing knowledge stores; and the updating of an existing episodic memory (Nadel et al., 2012; Rahmann \& Rahmann, 1992).

In the tourism scenario, experiences that create positive memories promote the intention to revisit the destination and recommend the destination to family and friends (Tung \& Ritchie, 2011). Ali et al. (2014) have shown that a positive consumer experience increases positive memories and increases destination loyalty. Halim and Mokhtar (2016) also highlight that positive experiences stimulate positive behaviour, activate positive memory processes, promote loyalty and increase word-of-month intention. 
It is possible to conclude that one of the key points of tourism success is the capacity to create positive memories among tourists.

According to Tung and Ritchie (2011), the four dimensions that represent memorable aspects of tourism experiences are affect, expectations, consequentiality and recollection. Affect refers to the positive emotions and feelings associated with the experiences, such as happiness and excitement. Expectations refer to the fulfilment of intentions and/or descriptions of surprises encountered during the trip that were above and beyond tourists' planned agendas. Consequentiality refers to the elements of perceived importance during the trip, such as social relationships, intellectual development, self-discovery, and physical challenges. Recollection refers to telling stories, showing photographs, purchasing souvenirs, re-experience the trip and going back and rebuilding the memory (Tung \& Ritchie, 2011).

\section{Conceptual Framework of the Senses, Emotions and Memories in the Memorable Tourism Experience}

The conceptual model shows the relationships established between the senses, emotions and memories to create a memorable tourism experience (see Figure 2).

The senses perceive the information (stimuli), the emotions interpret and understand the meaning of that information and, finally, the memory codifies and stores the information, if it is sufficiently important and extraordinary to the person (Agapito et al., 2014; Krishna, 2012; Lee et al., 2013). The sensory configuration of the tourism experience allows multisensory stimulation that increases the construction of positive emotional states and improves the development of memories (Barnes, Mattsson, \& Sørensen, 2014; Martins et al., 2017). Multisensory stimulation during the experience increases the creation of memorable experiences with high significance and results in the tourist's physical, emotional and intellectual involvement (Dias et al., 2017; Krishna \& Schwarz, 2014).

Once the environment information is perceived through the senses, the emotion stage extracts and explains the meaning of that information (Ekman, 2016). The emotional dimension of the touristic experience should focus on positive emotional states (Barrett, 2017; Correia et al., 2017; Kapoor, 2015; Oh et al., 2007; Tung et al., 2017), because positive emotional states build connections between individual people (Ekman, 2016) or between individuals and places (Correia et al., 2017; Dias et al., 2017), and these are essential in the decision-making processes for choosing a destination or experience (Bimonte \& Faralla, 2014; Esteves, Slongo, Esteves, \& Barcelos, 2013; Tung \& Ritchie, 2011). Emotional states such as joy, love and positive surprise are strongly correlated to emotional activation, emotional satisfaction and, consequently, memory creation, as well as general tourist satisfaction and behaviour intention to recommend or repeat (Chen et al., 2017; Hosany \& Prayag, 2013; Kurtz \& Welch, 2016; Prayag, Hosany, Muskat, \& Del Chiappa, 2017).

The relationship between emotions and memories results from the process of reminiscence - that is, the recollection and vividness of memories (Kim \& Youn, 2017). The tourist remembers the experiences through an emotional reconstruction of a particular experience (Lempert \& Phelps, 2016; Martins et al., 2017; Servidio \& Ruffolo, 2016). Emotions are thus particularly special in terms of quality and quantity during the experience, because they are crucial to the memory process (Correia et al., 2017; Dias et al., 2017). The memory of the experience is the result - that is, the memory encodes and stores only what the tourist perceives with his or her senses as emotionally pleasurable and as a focus of concentration and attention (Colombo \& Gold, 2004; Gold, 2004; Mizumori, Yeshenko, Gill, \& Davis, 2004; Todd, Talmi, Schmitz, Susskind, \& Anderson, 2012). According to Oh et al. (2007), the memory encodes and 
Figure 2. Conceptual framework of the senses, emotions and memories in the MTE Source: Own Elaboration

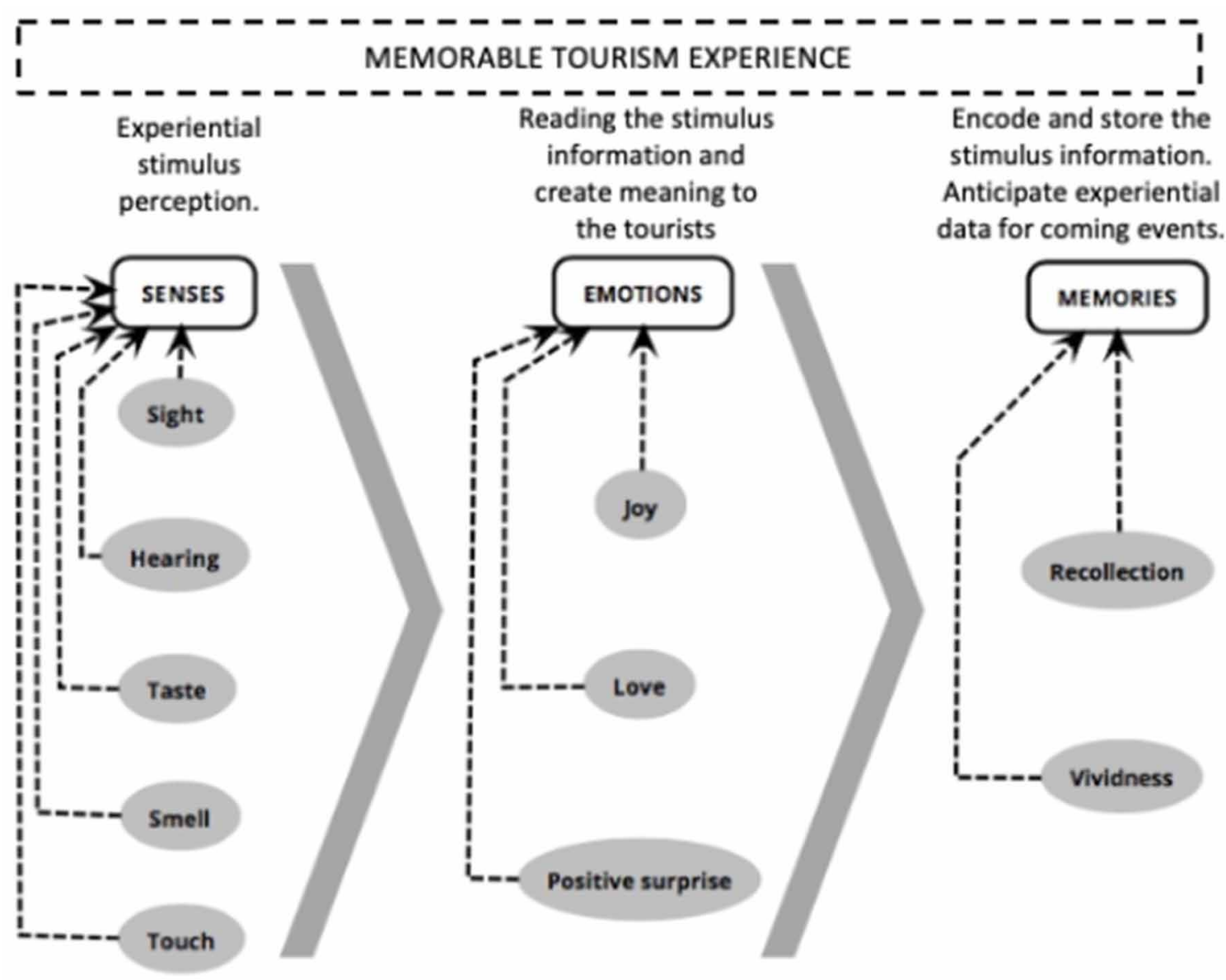

stores memorable moments if the experience involves elements that are wonderful, positive and yield long-term temporal perception.

\section{CONCLUSION}

Exploration of the three constructs (senses, emotions and memories) suggests that a memorable tourism experience is the result of a multisensory stimuli and perception, a positive emotional event, high emotional activity, an extraordinary and surprising emotional moment, wonderful and positive memories and a long-term memorable experience (Chen et al., 2017; Correia et al., 2017; Dias et al., 2017; Hosany \& Prayag, 2013; Kim, 2014; Kurtz \& Welch, 2016; Prayag et al., 2017). In the tourism context, the senses, emotions and memories are an important issue because multisensory stimuli encourage high emotional activity and increase the memory formation (Kim, 2018; Oh et al., 2007; Tung et al., 2017) because all sensory system is strongly related to emotional processes which involve cognitive processing, while the use of high cognitive resources are linked to the formation of memories (Zatori, 2013). 
Based on a critical and extensive literature review background, the future research opportunities in this area should explore the relationships between the constructs that lead to the creation of a memorable tourism experience. It is probable that they have a cyclic and sequential relationship: that is, the memory evokes the emotions experienced and these affect the decision-making process and behaviour intention to revisit the destination or repeat the experience (Chen et al., 2017; Hosany \& Prayag, 2013; Kurtz \& Welch, 2016; Prayag et al., 2017). In this particular investigation, the analyses began with the creation of the memorable tourism experience: sense, emotions and memories. The research gap emerges regarding the relationship between the senses, emotions and memories and the behavioural patterns discovered.

\section{ACKNOWLEDGMENT}

This research was supported by the National Funds provided by FCT - Foundation for Science and Technology through project UIDB/04020/2020.

\section{REFERENCES}

Adhikari, A., \& Bhattacharya, S. (2016). Appraisal of literature on customer experience in tourism sector: Review and framework. Current Issues in Tourism, 19(4), 296-321. doi:10.1080/13683500.2015.1082538

Agapito, D., Mendes, J., \& Valle, P. (2013). Exploring the conceptualization of the sensory dimension of tourist experiences. Journal of Destination Marketing \& Management, 2(2), 62-73. doi:10.1016/j. jdmm.2013.03.001

Agapito, D., Mendes, J., Valle, P., \& Almeida, H. (2014). A contribute to sensory marketing in rural tourist experiences. PASOS Revista de Turismo y Patrimonio Cultural, 12(3), 611-621. doi:10.25145/j. pasos.2014.12.045

Agapito, D., Valle, P., \& Mendes, J. (2014). The sensory dimension of tourist experiences: Capturing meaningful sensory-informed themes in Southwest Portugal. Tourism Management, 42, 224-237. doi:10.1016/j.tourman.2013.11.011

Ali, F., Hussain, K., \& Ragavan, N. (2014). Memorable Customer Experience: Examining the Effects of Customers Experience on Memories and Loyalty in Malaysian Resort Hotels. Procedia: Social and Behavioral Sciences, 144, 273-279. doi:10.1016/j.sbspro.2014.07.296

Ali, F., Ryu, K., \& Hussain, K. (2016). Influence of Experiences on Memories, Satisfaction and Behavioral Intentions: A Study of Creative Tourism. Journal of Travel \& Tourism Marketing, 33(1), 85-100. doi:10.1080/10548408.2015.1038418

Andajani, E. (2015). Understanding Customer Experience Management in Retailing. Procedia: Social and Behavioral Sciences, 211(September), 629-633. doi:10.1016/j.sbspro.2015.11.082

Arnold, M., \& Reynolds, K. (2003). Hedonic Shopping Motivations. Journal of Retailing, 79(2), 77-95. doi:10.1016/S0022-4359(03)00007-1 
Ayazlar, G., \& Arslan, R. (2017). A Cross-cultural Investigation of Tourists' Memorable Experiences Between Two Nationalities. Almatourism - Journal of Tourism. Culture and Territorial Development, 15(15), 136-151. doi:10.6092/issn.2036-5195/6558

Barnes, S., Mattsson, J., \& Sørensen, F. (2014). Destination brand experience and visitor behavior: Testing a scale in the tourism context. Annals of Tourism Research,48, 121-139. doi:10.1016/j.annals.2014.06.002

Barrett, L. (2017). How emotions are made: The secret life the brain. Houghton Mifflin Harcourt Publishing Company.

Baxendale, S., Macdonald, E., \& Wilson, H. (2015). The Impact of Different Touchpoints on Brand Consideration. Journal of Retailing, 91(2), 235-253. doi:10.1016/j.jretai.2014.12.008

Berry, L., Carbone, L., \& Haeckel, S. (2002). Managing the total customer experience. MIT Sloan Management Review, 43(3), 85-89. doi:10.1371/journal.pone.0015090

Bimonte, S., \& Faralla, V. (2014). Happiness and nature-based vacations. Annals of Tourism Research, 46, 176-178. doi:10.1016/j.annals.2014.02.002

Bosangit, C., Hibbert, S., \& McCabe, S. (2015). "If I was going to die I should at least be having fun": Travel blogs, meaning and tourist experience. Annals of Tourism Research, 55, 1-14. doi:10.1016/j. annals.2015.08.001

Boswijk, A., Thijssen, T., \& Peelen, E. (2006). A New Perspective on the Experience Economy - Meaningful Experiences. The European Centre for the Experience Economy, The Netherlands, 2, 233-247.

Brito, S., Oliveira, A., Nobre, L., Macedo, Á., \& Marchetti, R. (2017). Brand experience dimensions in the Brazilian context. Race, 16(4), 121-146. doi:10.18593/race.v16i1.10527

Buda, D., D'Hauteserre, A., \& Johnston, L. (2014). Feeling and tourism studies. Annals of Tourism Research, 46, 102-114. doi:10.1016/j.annals.2014.03.005

Buonincontri, P., Morvillo, A., Okumus, F., \& van Niekerk, M. (2017). Managing the experience cocreation process in tourism destinations: Empirical findings from Naples. Tourism Management, 62, 264-277. doi:10.1016/j.tourman.2017.04.014

Cabiddu, F., Lui, T., \& Piccoli, G. (2013). Managing Value Co-Creation In The Tourism Industry. Annals of Tourism Research, 42, 86-107. doi:10.1016/j.annals.2013.01.001

Campos, A., Mendes, J., Valle, P., \& Scott, N. (2015). Co-creation of tourist experiences: A literature review. Current Issues in Tourism, 21(April), 1-32. doi:10.1080/13683500.2015.1081158

Campos, A., Mendes, J., Valle, P., \& Scott, N. (2016). Co-Creation Experiences: Attention and Memorability. Journal of Travel \& Tourism Marketing, 33(9), 1309-1336. doi:10.1080/10548408.2015.1118424

Campos, A., Mendes, J., Valle, P., \& Scott, N. (2017). Co-creating animal-based tourist experiences: Attention, involvement and memorability. Tourism Management, 63, 100-114. doi:10.1016/j.tourman.2017.06.001

Carbone, L., \& Haeckel, S. (1994). Engineering Customer Experiences. Marketing Management, 3(3), 8-19. 
Carù, A., \& Cova, B. (2003). Revisiting Consumption Experience: A More Humble but Complete View of the Concept. Marketing Theory, 3(2), 267-286. doi:10.1177/14705931030032004

Chahal, H., Kaur, G., \& Rani, A. (2016). Exploring the Dimensions of Customer Experience and its Impact on Word-of-Mouths: A Study of Credit Cards. Journal of Services Research, 15(2), 1-33. https:// search.proquest.com/abicomplete/docview/1878857032/8DF011A210874C67PQ/4?accountid=132208

Chan, W., To, C., \& Chu, W. (2016). Desire for experiential travel, avoidance of rituality and social esteem: An empirical study of consumer response to tourism innovation. Journal of Innovation \& Knowledge, 1(1), 24-35. doi:10.1016/j.jik.2016.02.001

Chandralal, L., \& Valenzuela, F.-R. (2013). Exploring Memorable Tourism Experiences: Antecedents and Behavioural Outcomes. Journal of Economics. Business and Management, 1(2), 177-181.

Chandralal, L., \& Valenzuela, F.-R. (2015). Memorable Tourism Experiences: Scale Development. Contemporary Management Research, 11(3), 291-310. doi:10.7903/cmr.13822

Chang, S. (2018). Experience economy in hospitality and tourism: Gain and loss values for service and experience. Tourism Management, 64, 55-63. doi:10.1016/j.tourman.2017.08.004

Chang, S.-H., \& Lin, R. (2015). Building a Total Customer Experience Model: Applications for the Travel Experiences in Taiwan's Creative Life Industry. Journal of Travel \& Tourism Marketing, 32(4), 438-453. doi:10.1080/10548408.2014.908158

Chen, H., \& Rahman, I. (2018). Cultural tourism: An analysis of engagement, cultural contact, memorable tourism experience and destination loyalty. Tourism Management Perspectives, 26, 153-163. doi:10.1016/j.tmp.2017.10.006

Chen, L., Scott, N., \& Benckendorff, P. (2017). Mindful tourist experiences: A Buddhist perspective. Annals of Tourism Research, 64, 1-12. doi:10.1016/j.annals.2017.01.013

Cohen, E. (1979). A Phenomenology of Tourist Experiences. Sociology, 13(2), 179-201. doi:10.1177/003803857901300203

Cohen, E., \& Ben-Nun, L. (2009). The Important Dimensions of Wine Tourism Experience from Potential Visitors' Perception. Tourism and Hospitality Research, 9(1), 20-31. doi:10.1057/thr.2008.42

Colombo, P., \& Gold, P. (2004). Multiple memory systems. Neurobiology of Learning and Memory, 82(3), 169-170. doi:10.1016/j.nlm.2004.07.008 PMID:15464401

Correia, A., Oliveira, C., \& Pereira, R. (2017). From Emotions to Place Attachment. In A. Correia, M. Kozak, J. Gnoth, \& A. Fyall (Eds.), Co-Creation and Well-Being in Tourism (pp. 163-177). Springer International Publishing. doi:10.1007/978-3-319-44108-5_13

Csikszentmihalyi, M. (1990). Flow - The Psychology of optimal experience. Academy of Management Review. New York: HarperCollins Publishers Inc. doi:10.5465/AMR.1991.4279513

Csikszentmihalyi, M. (1997). Finding Flow - The Psychology of Engagement with Everyday Life. New York: Basic Books. 
Csikszentmihalyi, M. (2014). Flow and the Foundations of Positive Psychology. Dordrecht: Springer. doi:10.1007/978-94-017-9088-8

Dalgleish, T. (2004). The emotional brain. Nature Reviews. Neuroscience, 5(7), 583-589. doi:10.1038/ nrn1432 PMID: 15208700

Damásio, A. (2010). Self Comes to Mind: Constructing the Conscious Brain. Random House.

Dann, G., \& Jacobsen, J. (2003). Tourism smellscapes. Tourism Geographies, 5(1), 3-25. doi:10.1080/1461668032000034033

Deak, A. (2011). Brain and emotion: Cognitive neuroscience of emotions. Review of Psychology, 18(2), $71-80$.

Demarco, D. (2016). Sustainable Urban Development Perspectives in the Era of Tourism Experience. Procedia: Social and Behavioral Sciences, 223, 335-341. doi:10.1016/j.sbspro.2016.05.236

Dhebar, A. (2013). Toward a compelling customer touchpoint architecture. Business Horizons, 56(2), 199-205. doi:10.1016/j.bushor.2012.11.004

Dias, J., Correia, A., \& Cascais, T. (2017). Traits in Tourists' Experiences: Senses, Emotions and Memories. In A. Correia, M. Kozak, J. Gnoth, \& A. Fyall (Eds.), Co-Creation and Well-Being in Tourism (pp. 179-194). Springer International Publishing. doi:10.1007/978-3-319-44108-5_14

Ding, C., \& Tseng, T. (2015). On the relationships among brand experience, hedonic emotions, and brand equity. European Journal of Marketing, 49(7/8), 994-1015. doi:10.1108/EJM-04-2013-0200

Dirsehan, T., \& Çelik, M. (2011). Profiling online consumers according to their experiences with a special focus on social dimension. Procedia: Social and Behavioral Sciences, 24, 401-412. doi:10.1016/j. sbspro.2011.09.040

Ditoiu, M.-C., \& Căruntu, A.-L. (2014). Sensory Experiences Regarding Five-dimensional Brand Destination. Procedia: Social and Behavioral Sciences, 109, 301-306. doi:10.1016/j.sbspro.2013.12.461

Duarte, P. (2012). Tourist experience: Contemporary perspectives. Journal of Heritage Tourism, 7(2), 187-188. doi:10.1080/1743873X.2011.638459

Duncan, E., Fanderl, H., Maechler, N., \& Neher, K. (2016). Customer experience: Creating value through transforming customer journeys (Vol. 1). McKinsey \& Company., doi:10.1057/9780230291775

Ek, R., Larsen, J., Hornskov, S. B., \& Mansfeldt, O. K. (2008). A dynamic framework of tourist experiences: Space-time and performances in the experience economy. Scandinavian Journal of Hospitality and Tourism, 8(2), 122-140. doi:10.1080/15022250802110091

Ekman, P. (2016). What Scientists Who Study Emotion Agree About. Perspectives on Psychological Science, 11(1), 31-34. doi:10.1177/1745691615596992 PMID:26817724

Esteves, P., Slongo, L., Esteves, C., \& Barcelos, R. (2013). As emoções dos consumidores da terceira idade no processo de escolha de destinos de viagens. Revista de Administração Da UFSM, 6(3), 561-580. doi:10.5902/198346595581 
Fave, A., \& Bassi, M. (2016). Flow Experience: Empirical Research and Applications. doi:10.1007/9783-319-28634-1_1

Fernandes, T., \& Cruz, M. (2016). Dimensions and outcomes of experience quality in tourism: The case of Port wine cellars. Journal of Retailing and Consumer Services, 31, 371-379. doi:10.1016/j. jretconser.2016.05.002

Foris, D. (2014). Study Regarding a New Dimension of Tourism Phenomenon-The Political-Administrative Dimension. Procedia: Social and Behavioral Sciences, 143, 1078-1082. doi:10.1016/j.sbspro.2014.07.559

Gelter, H. (2010). Total Experience Management - a conceptual model for transformational experiences within tourism. In The Nordic Conference on Experience 2008. Research, Education and Practice in Media (pp. 46-78). Vaasa: Medusa Group of Vaasa Consortium of Higher Education.

Gentile, C., Spiller, N., \& Noci, G. (2007). How to Sustain the Customer Experience. An Overview of Experience Components that Co-create Value With the Customer. European Management Journal, 25(5), 395-410. doi:10.1016/j.emj.2007.08.005

Goggin, C., Please, P., Ridges, M., Booth, C., Simpson, G., Green, R., \& Leys, J. (2017). Connecting with Country in Mungo National Park, Australia: A case study to measure the emotional dimension of experience and place attachment. Local Environment, 22(10), 1217-1236. doi:10.1080/13549839.201 7.1334142

Gold, P. (2004). Coordination of multiple memory systems. Neurobiology of Learning and Memory, 82(3), 230-242. doi:10.1016/j.nlm.2004.07.003 PMID:15464406

Guzel, O. (2014). The Dimensions of Tour Experience, Emotional Arousal, and Post-experience Behaviors: A Research on Pamukkale in Turkey. Procedia: Social and Behavioral Sciences, 150, 521-530. doi:10.1016/j.sbspro.2014.09.069

Halim, A., \& Mokhtar, A. (2016). Creating Memorable Visitor Experiences by Assessing the Satisfaction Level and Behavioural Consequences of Attendees. Procedia Economics and Finance, 37, 1-6. doi:10.1016/S2212-5671(16)30084-3

Holbrook, M., \& Hirschman, E. (1982). The Experiential Aspects of Consumption: Consumer Fantasies, Feelings, and Fun. The Journal of Consumer Research, 9(2), 132. doi:10.1086/208906

Hosany, S., \& Prayag, G. (2013). Patterns of tourists' emotional responses, satisfaction, and intention to recommend. Journal of Business Research, 66(6), 730-737. doi:10.1016/j.jbusres.2011.09.011

Hosany, S., Prayag, G., Deesilatham, S., Cauševic, S., \& Odeh, K. (2015). Measuring Tourists' Emotional Experiences: Further Validation of the Destination Emotion Scale. Journal of Travel Research, 54(4), 482-495. doi:10.1177/0047287514522878

Hosany, S., Prayag, G., Van Der Veen, R., Huang, S., \& Deesilatham, S. (2017). Mediating Effects of Place Attachment and Satisfaction on the Relationship between Tourists' Emotions and Intention to Recommend. Journal of Travel Research, 56(8), 1079-1093. doi:10.1177/0047287516678088

Hosany, S., \& Witham, M. (2010). Dimensions of Cruisers' Experiences, Satisfaction, and Intention to Recommend. Journal of Travel Research, 49(3), 351-364. doi:10.1177/0047287509346859 
Hsieh, S., \& Chang, A. (2016). The Psychological Mechanism of Brand Co-creation Engagement. Journal of Interactive Marketing, 33, 13-26. doi:10.1016/j.intmar.2015.10.001

Ivanovic, M., \& Saayman, M. (2015). Authentic economy shaping transmodern tourism experience. African Journal for Physical, Health Education. Recreation and Dance, (Supplement), 24-36.

Jalis, M. H., Che, D., \& Markwell, K. (2014). Utilising Local Cuisine to Market Malaysia as a Tourist Destination. Procedia: Social and Behavioral Sciences, 144, 102-110. doi:10.1016/j.sbspro.2014.07.278

Jennings, G. (2005). Perspectives on quality tourism experiences: An introduction. In G. Jennings \& N. P. Nickerson (Eds.), Quality Tourism Experiences (pp. 1-21). Elsevier Ltd., doi:10.4324/9780080455778

Jensen, R. (2001). The Dream Society: How the Coming Shift from Information to Imagination will Transform Your Business (2nd ed.). McGraw-Hill.

Jepson, D., \& Sharpley, R. (2015). More than sense of place? Exploring the emotional dimension of rural tourism experiences. Journal of Sustainable Tourism, 23(8-9), 1157-1178. doi:10.1080/096695 82.2014 .953543

Kapoor, A. (2015). Consumer Experiences and Emotion Management (N. Malhotra, Ed.). Business Expert Press.

Kastenholz, E., Carneiro, M., Marques, C., \& Loureiro, S. (2017). The dimensions of rural tourism experience: Impacts on arousal, memory, and satisfaction. Journal of Travel \& Tourism Marketing, 35(2), 1-13. doi:10.1080/10548408.2017.1350617

Killion, G. (1992). Understanding tourism. Study Guide.

Kim, J., \& Fesenmaier, D. (2015). Designing Tourism Places: Understanding the Tourism Experience through our Senses. In Tourism Travel and Research Association - Turning Insights into Actions, the Crucial Role of Tourism Research (p. 5). Travel and Tourism Research Association. Retrieved from https://scholarworks.umass.edu/ttra/ttra2015/Academic_Papers_Oral/19

Kim, J.-H. (2010). Determining the factors affecting the memorable nature of travel experiences. Journal of Travel \& Tourism Marketing, 27(8), 780-796. doi:10.1080/10548408.2010.526897

Kim, J.-H. (2014). The antecedents of memorable tourism experiences: The development of a scale to measure the destination attributes associated with memorable experiences. Tourism Management, 44, 34-45. doi:10.1016/j.tourman.2014.02.007

Kim, J.-H. (2018). The Impact of Memorable Tourism Experiences on Loyalty Behaviors: The Mediating Effects of Destination Image and Satisfaction. Journal of Travel Research, 57(7), 856-870. doi:10.1177/0047287517721369

Kim, J.-H., \& Jang, S. (2016). Memory Retrieval of Cultural Event Experiences: Examining Internal and External Influences. Journal of Travel Research, 55(3), 322-339. doi:10.1177/0047287514553058

Kim, J.-H., \& Ritchie, J. (2014). Cross-Cultural Validation of a Memorable Tourism Experience Scale (MTES). Journal of Travel Research, 53(3), 323-335. doi:10.1177/0047287513496468 
Kim, J.-H., Ritchie, J., \& McCormick, B. (2012). Development of a scale to measure memorable tourism experiences. Journal of Travel Research, 51(1), 12-25. doi:10.1177/0047287510385467

Kim, J.-H., \& Youn, H. (2017). How to Design and Deliver Stories about Tourism Destinations. Journal of Travel Research, 56(6), 808-820. doi:10.1177/0047287516666720

Kirillova, K., Lehto, X., \& Cai, L. (2017). What triggers transformative tourism experiences? Tourism Recreation Research, 42(4), 498-511. doi:10.1080/02508281.2017.1342349

Krishna, A. (2012). An integrative review of sensory marketing: Engaging the senses to affect perception, judgment and behavior. Journal of Consumer Psychology, 22(3), 332-351. Advance online publication. doi:10.1016/j.jcps.2011.08.003

Krishna, A., \& Schwarz, N. (2014). Sensory marketing, embodiment, and grounded cognition: A review and introduction. Journal of Consumer Psychology, 24(2), 159-168. doi:10.1016/j.jcps.2013.12.006

Kurtz, J., \& Welch, C. (2016). The Emotion of Happiness. In H. L. Meiselman (Ed.), Emotions Measurement. Elsevier Ltd. doi:10.1016/B978-0-08-100508-8.00020-5

Larsen, S. (2007). Aspects of a Psychology of the Tourist Experience. Scandinavian Journal of Hospitality and Tourism, 7(1), 7-18. doi:10.1080/15022250701226014

LeDoux, J. (2012). Rethinking the Emotional Brain. Neuron, 73(4), 653-676. doi:10.1016/j.neuron.2012.02.004 PMID:22365542

Lee, S., Heere, B., \& Chung, K. (2013). Which Senses Matter More? The Impact of Our Senses on Team Identity and Team Loyalty. Sport Marketing Quarterly, 22(4), 203-213. http://search.ebscohost.com/ login.aspx ?direct $=$ true $\& \mathrm{db}=\mathrm{bth} \& \mathrm{AN}=93709410 \&$ lang $=$ pt-br\&site=ehost-live

Lemon, K., \& Verhoef, P. (2016). Understanding Customer Experience Throughout the Customer Journey. Journal of Marketing, 80(6), 69-96. doi:10.1509/jm.15.0420

Lempert, K., \& Phelps, E. (2016). Affect in Economic Decision Making. In L. F. Barrett, M. Lewis, \& J. M. Haviland-Jones (Eds.), Handbook of Emotions (4th ed., Vol. 1, pp. 98-112). The Guilford Press.

Light, D. (2009). The Senses: The Human Body, How It Works. Chelsea House Publishers.

Lin, Z., Chen, Y., \& Filieri, R. (2017). Resident-tourist value co-creation: The role of residents' perceived tourism impacts and life satisfaction. Tourism Management, 61, 436-442. doi:10.1016/j.tourman.2017.02.013

Martins, J., Gonçalves, R., Branco, F., Barbosa, L., Melo, M., \& Bessa, M. (2017). A multisensory virtual experience model for thematic tourism: A Port wine tourism application proposal. Journal of Destination Marketing \& Management, 6(2), 103-109. doi:10.1016/j.jdmm.2017.02.002

Marx, G., \& Gilon, C. (2012). The Molecular Basis of Memory. ACS Chemical Neuroscience, 3(8), 633-642. doi:10.1021/cn300097b PMID:23050060

Meacci, L., \& Liberatore, G. (2015). Towards a Senses-Based Model for Experimental Tourism: The YOUTOOSCANY.COM Case. Proceedings 1st International Conference on Experiential Tourism, (10), 9-11. 
Mendes, J., Guerreiro, M., \& Matos, N. (2016). Monitoring the Quality of Tourism Experience. Proceedings of the Asia Tourism Forum 2016 - the 12Th Biennial Conference of Hospitality and Tourism Industry in Asia, 19(1), 294-304. 10.2991/atf-16.2016.44

Mizumori, S., Yeshenko, O., Gill, K., \& Davis, D. (2004). Parallel processing across neural systems: Implications for a multiple memory system hypothesis. Neurobiology of Learning and Memory, 82(3), 278-298. doi:10.1016/j.nlm.2004.07.007 PMID:15464410

Morgan, M. (2006). Making space for experiences. Journal of Retail \& Leisure Property, 5(4), 305-313. doi:10.1057/palgrave.rlp.5100034

Mossberg, L. (2007). A Marketing Approach to the Tourist Experience. Scandinavian Journal of Hospitality and Tourism, 7(1), 59-74. doi:10.1080/15022250701231915

Nadel, L., Hupbach, A., Gomez, R., \& Newman-Smith, K. (2012). Memory formation, consolidation and transformation. Neuroscience and Biobehavioral Reviews, 36(7), 1640-1645. doi:10.1016/j.neubiorev.2012.03.001 PMID:22465050

Nasution, R., Sembada, A., Miliani, L., Resti, N., \& Prawono, D. (2014). The Customer Experience Framework as Baseline for Strategy and Implementation in Services Marketing. Procedia: Social and Behavioral Sciences, 148, 254-261. doi:10.1016/j.sbspro.2014.07.041

Nickerson, N. (2005). Some Reflections on Quality Tourism Experiences. In G. Jennings \& N. P. Nickerson (Eds.), Quality Tourism Experiences (pp. 227-236). Elsevier Ltd.

Oh, H., Fiore, A., \& Jeoung, M. (2007). Measuring Experience Economy Concepts: Tourism Applications. Journal of Travel Research, 46(2), 119-132. doi:10.1177/0047287507304039

Park, S., \& Santos, C. (2017). Exploring the Tourist Experience. A Sequential Approach. Journal of Travel Research, 56(1), 16-27. doi:10.1177/0047287515624017

Pawaskar, P., \& Goel, M. (2014). A Conceptual Model: Multisensory Marketing and Destination Branding. Procedia Economics and Finance, 11(11), 255-267. doi:10.1016/S2212-5671(14)00194-4

Peñaloza, L., \& Venkatesh, A. (2006). Further evolving the new dominant logic of marketing: From services to the social construction of markets. Marketing Theory, 6(3), 299-316. doi:10.1177/1470593106066789

Pentus, K., Mehine, T., \& Kuusik, A. (2014). Considering Emotions in Product Package Design through Combining Conjoint Analysis with Psycho Physiological Measurements. Procedia: Social and Behavioral Sciences, 148, 280-290. doi:10.1016/j.sbspro.2014.07.044

Perritano, J. (2011). Science of Emotions. Marshall Cavendish Benchmark.

Pezzi, E., \& Vianna, S. (2015). Tourist Experience and Experiential Tourism: A study about dimensions of memorable experience. Turismo Em Análise, 26(1), 165-187. doi:10.11606/issn.1984-4867. v26i1p165-187

Phelps, E. A. (2004). Human emotion and memory: Interactions of the amygdala and hippocampal complex. Current Opinion in Neurobiology, 14(2), 198-202. doi:10.1016/j.conb.2004.03.015 PMID:15082325 
Pine, J., \& Gilmore, J. (1998). Welcome to the Experience Economy. Harvard Business Review, 76(4), 97-105. PMID:10181589

Pine, J., \& Gilmore, J. (1999). The Experience Economy: Work is Theater \& Every Business a Stage. Harvard Business School Press.

Prayag, G., Hosany, S., Muskat, B., \& Del Chiappa, G. (2017). Understanding the Relationships between Tourists' Emotional Experiences, Perceived Overall Image, Satisfaction, and Intention to Recommend. Journal of Travel Research, 56(1), 41-54. doi:10.1177/0047287515620567

Prayag, G., Hosany, S., \& Odeh, K. (2013). The role of tourists' emotional experiences and satisfaction in understanding behavioral intentions. Journal of Destination Marketing \& Management, 2(2), 118-127. doi:10.1016/j.jdmm.2013.05.001

Prebensen, N., Vitterso, J., \& Dahl, T. (2013). Value Co-creation Significance of Tourist Resources. Annals of Tourism Research, 42, 240-261. doi:10.1016/j.annals.2013.01.012

Prebensen, N., \& Xie, J. (2017). Efficacy of co-creation and mastering on perceived value and satisfaction in tourists' consumption. Tourism Management, 60, 166-176. doi:10.1016/j.tourman.2016.12.001

Pyke, S., Hartwell, H., Blake, A., \& Hemingway, A. (2016). Exploring well-being as a tourism product resource. Tourism Management, 55, 94-105. doi:10.1016/j.tourman.2016.02.004

Quadri-Felitti, D., \& Fiore, A. (2013). Destination loyalty: Effects of wine tourists' experiences, memories, and satisfaction on intentions. Tourism and Hospitality Research, 13(1), 47-62. doi: $10.1177 / 1467358413510017$

Rahmann, H., \& Rahmann, M. (1992). The Neurobiological Basis of Memory and Behavior. Springer. doi:10.1007/978-1-4612-2772-4

Rais, N., Musa, R., \& Muda, M. (2016). Reconceptualisation of Customer Experience Quality (CXQ) Measurement Scale. Procedia Economics and Finance, 37(16), 299-303. doi:10.1016/S2212-5671(16)30128-9

Ramaswamy, V., \& Ozcan, K. (2018). What is co-creation? An interactional creation framework and its implications for value creation. Journal of Business Research, 84, 196-205. doi:10.1016/j. jbusres.2017.11.027

Ribes-Giner, G., Perello-Marín, M., \& Díaz, O. (2016). Co-creation Impacts on Student Behavior. Procedia: Social and Behavioral Sciences, 228, 72-77. doi:10.1016/j.sbspro.2016.07.011

Salmela, M. (2014). True Emorions (R. Ellis \& P. Zachar, Eds.). John Benjamins Publishing Company.

Schmitt, B. (1999). Experiential marketing. Journal of Marketing Management, 15(1-3), 53-67. doi:10.1362/026725799784870496

Schmitt, B., Brakus, J., \& Zarantonello, L. (2015). From experiential psychology to consumer experience. Journal of Consumer Psychology, 25(1), 166-171. doi:10.1016/j.jcps.2014.09.001

Servidio, R., \& Ruffolo, I. (2016). Exploring the relationship between emotions and memorable tourism experiences through narratives. Tourism Management Perspectives, 20, 151-160. doi:10.1016/j. tmp.2016.07.010 
Shaw, C. (2005). Revolutionize Your Customer Experience (1st ed.). Palgrave Macmillan. doi:10.1057/9780230513457

Shoval, N., Schvimer, Y., \& Tamir, M. (2018). Real-Time Measurement of Tourists' Objective and Subjective Emotions in Time and Space. Journal of Travel Research, 57(1), 3-16. doi:10.1177/0047287517691155

Stasiak, A. (2013). Tourist Product in Experience Economy. Tourism (Zagreb), 23(1), 27-35. doi:10.1016/j. tourman.2015.08.005

Stein, A., \& Ramaseshan, B. (2016). Towards the identification of customer experience touch point elements. Journal of Retailing and Consumer Services, 30, 8-19. doi:10.1016/j.jretconser.2015.12.001

Sthapit, E. (2017). Exploring tourists' memorable food experiences: A study of visitors to Santa's official hometown. Anatolia, 28(3), 404-421. doi:10.1080/13032917.2017.1328607

Sthapit, E., \& Coudounaris, D. (2018). Memorable tourism experiences: Antecedents and outcomes. Scandinavian Journal of Hospitality and Tourism, 18(1), 72-94. doi:10.1080/15022250.2017.1287003

Todd, R., Talmi, D., Schmitz, T., Susskind, J., \& Anderson, A. (2012). Psychophysical and neural evidence for emotion enhanced perceptual vividness. The Journal of Neuroscience: The Official Journal of the SocietyforNeuroscience,32(33), 11201-11212. doi:10.1523/JNEUROSCI.0155-12.2012PMID:22895705

Tsai, C.-T. (2016). Memorable Tourist Experiences and Place Attachment When Consuming Local Food. International Journal of Tourism Research, 18(6), 536-548. doi:10.1002/jtr.2070

Tung, V., Lin, P., Zhang, H., \& Zhao, A. (2017). A framework of memory management and tourism experiences. Journal of Travel \& Tourism Marketing, 34(7), 853-866. doi:10.1080/10548408.2016.1260521

Tung, V., \& Ritchie, J. (2011). Exploring the essence of memorable tourism experiences. Annals of Tourism Research, 38(4), 1367-1386. doi:10.1016/j.annals.2011.03.009

Tussyadiah, I. (2014). Toward a Theoretical Foundation for Experience Design in Tourism. Journal of Travel Research, 53(5), 543-564. doi:10.1177/0047287513513172

Tynan, C., \& McKechnie, S. (2009). Experience marketing: A review and reassessment. Journal of Marketing Management, 25(5-6), 501-517. doi:10.1362/026725709X461821

Verhoef, P., Lemon, K., Parasuraman, A., Roggeveen, A., Tsiros, M., \& Schlesinger, L. (2009). Customer Experience Creation: Determinants, Dynamics and Management Strategies. Journal of Retailing, 85(1), 31-41. doi:10.1016/j.jretai.2008.11.001

Vo Thanh, T., \& Kirova, V. (2018). Wine tourism experience: A netnography study. Journal of Business Research, 83, 30-37. doi:10.1016/j.jbusres.2017.10.008

Volo, S. (2009). Conceptualizing Experience: A Tourist Based Approach. Journal of Hospitality \& Leisure Marketing, 18(2-3), 111-126. doi:10.1080/19368620802590134

Wang, L., Tang, H., Liu, D., \& Xing, C. (2017). Study on Customer Experience Dimension Based on Online Shopping reviews of MI's Products. In MATEC Web of Conferences (Vol. 100, pp. 1-7). Academic Press. 
Zatori, A. (2013). Tourism Experience Creation From a Business Perspective. Corvinus University of Budapest. Retrieved from http://phd.lib.uni-corvinus.hu/801/7/Zatori_Anita_den.pdf

Zatori, A., Smith, M. K., \& Puczko, L. (2018). Experience-involvement, memorability and authenticity: The service provider's effect on tourist experience. Tourism Management, 67, 111-126. doi:10.1016/j. tourman.2017.12.013

Zhang, H., Wu, Y., \& Buhalis, D. (2018). A model of perceived image, memorable tourism experiences and revisit intention. Journal of Destination Marketing and Management, 8, 326-336. doi:10.1016/j. jdmm.2017.06.004

\section{ADDITIONAL READING}

Bakker, I., van der Voordt, T., Vink, P., \& Boon, J. (2014). Pleasure, Arousal, Dominance: Mehrabian and Russell revisited. Current Psychology (New Brunswick, N.J.), 33(3), 405-421. doi:10.100712144014-9219-4

Bjorklund, R. (2010). The Amazing Human Body: The Senses. Marshall Cavendish Benchmark, NY: Tarrytown.

Nalbantian, S., Matthews, P. M., \& McClelland, J. L. (2011). The Memory Process: Neuroscientific and Humanistic Perspectives. The MIT Press, Massachusetts: Cambridge. Fayos-Solà, E. \& Cooper, C. (2019). The Future of Tourism: Innovation and Sustainability. Springer International Publishing, Switzerland: Cham.

Skavronskaya, L., Moylea, B., Scott, N., \& Schaffer, V. (2019). Collecting Memorable Tourism Experiences: How Do 'wechat'? Journal of China Tourism Research, •••, 1-23. doi:10.1080/19388160.201 9.1656131

Tugade, M. M., Shiota, M. N., \& Kirby, L. D. (2014). The Handbook of Positive Emotions. Guilford Press, NY: New York.

Yan, N., \& Halpenny, E. A. (2019). Tourists' savoring of positive emotions and place attachment formation: A conceptual paper. Tourism Geographies, 1-21. Advance online publication. doi:10.1080/1461 6688.2019.1647454 


\section{key TERMS and definitions}

Arousal: Comprehends the autonomic nervous system activation, is the level of mental alertness and physical activity and ranges from sleep through intermediate states of drowsiness and then alertness to frenzied excitement at the opposite extreme (e.g. sleep, inactivity, boredom, and relaxation at the lower end versus wakefulness, bodily tension, strenuous exercise, and concentration at the higher end).

Endocrinal Response: Is a chemical response at internal or endocrinal level caused by hormones released by glands directly into the circulatory system that fostering visceral changes.

Homeostasis: This is the condition of optimal functioning for the organism and includes the steady state of many variables maintained, such as: internal, physical and chemical.

Long-Term Memory: Information is held in mind for a long period of time, between days, months or all life. The long-term memory is an outcome of the information resulting from short-term memory, plus a strong emotional connection, and a repetition process (or recall process).

Memorable Tourism Experience (MTE): Is a tourism experience remembered and recalled after the event has occurred.

Plasticity: Is the ability of the humans to change continually throughout is life as a result of experiences and is the level of individual's adaptability of the environment changes. These changes occur at the brain level (neuroplasticity), emotional, cognition, social, cultural, etc.

Sensation: Is the physical process during which sensory systems respond to a stimulus and provide sensorial data for stimulus perception. The sensation consists in five stages, i.e.: signal recognition, stimulus collection, transduction, transmission via afferent, central processing (brain), transmission via efferent and response/action (biochemical response and motor action).

Sensorial Memory: Know as bodily memory too, is a memory information from the sensorial stimulus inputs information and is held in mind during 0.2 to 2 seconds.

Short-Term Memory: Information is typically held in mind for a relatively short period of time, between 2 to 60 seconds, before being forgotten. This specifically memory is the resulting from sensorial memory, more an emotional outcome and attention.

Tourism Experience Relational Model: Is a model that allows to relate all those involved in the tourist experience establishment, such as: the experience dimensions, experience stages and actions, touchpoints, antecedents and outcomes to defining and framing the tourist experience in a holistic and comprehensive state. 